\title{
BMJ Open Off-label drug prescriptions in French general practice: a cross-sectional study
}

\author{
François Drogou, ${ }^{1}$ Allison Netboute, ${ }^{1}$ Joris Giai, ${ }^{2}$ Xavier Dode,${ }^{3}$ David Darmon, ${ }^{4}$ \\ Behrouz Kassai, ${ }^{5,6}$ Laurent Letrilliart ${ }^{1,7}$
}

To cite: Drogou F, Netboute A, Giai J, et al. Off-label drug prescriptions in French general practice: a crosssectional study. BMJ Open 2019;9:e026076. doi:10.1136/ bmjopen-2018-026076

- Prepublication history for this paper is available online. To view these files, please visit the journal online (http://dx.doi. org/10.1136/bmjopen-2018026076).

$\mathrm{FD}$ and $\mathrm{AN}$ contributed equally.

Received 15 August 2018 Revised 18 January 2019 Accepted 12 March 2019

Check for updates

(C) Author(s) (or their employer(s)) 2019. Re-use permitted under CC BY-NC. No commercial re-use. See rights and permissions. Published by BMJ.

For numbered affiliations see end of article.

Correspondence to Professor Laurent Letrilliart; laurent.letrilliart@univ-lyon1.fr

\section{ABSTRACT}

Objectives Off-label drug prescribing is a public health and economic issue. The aim of this study was to describe off-label prescription in general practice in France, in terms of frequency and nature, and to identify its main determining factors.

Design Multicentre cross-sectional study

Setting Twenty-three training general practice offices

Participants All the voluntary patients coming for a medical consultation or visited at home over a cumulative period of 5 days per office between November 2015 and January 2016.

Methods Eleven interns, acting as observers, collected data. Two reviewers analysed the drugs prescribed by the trainers, in order to identify those prescribed off-label in terms of their indication or the age of the patient. We used a univariate, then a multivariate model, based on hierarchical mixed-effects logistic regression.

Results Among the 4932 drug prescriptions registered, 911 (18.5\%[95\% Cl17.4\% to $19.6 \%]$ ) were off-label, of which $865(17.6 \%)$ due to the indication of the drug and $58(1.2 \%)$ due to the age of the patient. The prescription never mentioned the off-label use, neither was the patient informed of it, as required by the French law. With the multivariate analysis, variables contributing to off-label prescription were the number of drugs $(\mathrm{OR}=1.05 \mathrm{for}$ each additional drug), the initiation of new drug therapy $(\mathrm{OR}=1.26)$ and the non-specific goal of the prescription $(O R=1.43)$; the age of the patient $\leq 14$ years $(0 R=1.42)$; the rural location of the physician's practice $(\mathrm{OR}=1.38)$ and the low frequency of the visits of national health insurance representatives $(\mathrm{OR}=0.93)$.

Conclusion Almost one out of five drugs prescribed in French general practice was off-label. It seems necessary to better train physicians in clinical pharmacology, to provide them with more effective drug prescription software, to reinforce postmarketing surveillance and to clearly define off-label use by consensus.

\section{INTRODUCTION}

Marketing authorisation (MA) is mandatory before marketing medicine, thus ensuring the safety, the quality and the efficacy of the drug. ${ }^{12}$ In the USA, the Food and Drug Administration (FDA) issues the MA since 1962, and is competent on the entire federal state. $^{2}$ The FDA-approved labelling for a drug provides the prescribing information or package insert (PI) to the practitioners and
Strengths and limitations of this study

No data were missing from the database we used.

- The off-label status of each drug prescription was double assessed.

- The study involved general practice trainers, which could entail a selection bias.

- We only studied off-label prescribing in terms of indication and age, without including the dosage, route of administration and drug interaction risks.

the patient package insert to the patients. The PI contains two main components: the highlights of PI (HPI) and the full PI. ${ }^{3}$ In Europe, the European Medicines Agency (EMA) issues the MA since $1995 .{ }^{4}$ National MA exists in France since 1941, ${ }^{5}$ and has been completed by three procedures to harmonise drug approval between the European Union countries: centralised, mutual recognition and decentralised. ${ }^{6}$ The European MA has three annexes: the summary of product characteristics (SPC) for healthcare professionals, the medication leaflet for patients and the label with the packaging. Both the HPI and the SPC include the name of the medicinal product, the composition, the pharmaceutical form, the therapeutic indications, the clinical particulars (posology and method of administration), warnings and precautions for use, contraindications and adverse effects of the product. ${ }^{7}$ However, there has been substantial disagreement in the information available to prescribers and patients in different countries. ${ }^{8}$

Drugs are not always used according to the MA criteria in medical practice. Any intentional use of an authorised product not covered by the terms of its MA is considered an off-label prescription. This may, for example, be the use for a different indication, use of a different dosage, dosing frequency or duration of use, use of a different method of administration or use by a different patient group. ${ }^{1}$ Off-label prescribing is a public health and economic issue. The quality and 
the safety of a prescribed drug are not ensured outside of its MA. Off-label prescribing increases iatrogenic risks by a factor of 1.4 , whether in adults or children. ${ }^{910}$ Besides, there is not always scientific studies to assess its effectiveness. Finally, many off-label prescribed drugs are more expansive for the patient and/or the community. ${ }^{11}$

Evaluations on off-label drug prescribing performed until now were limited to a setting (mostly the hospital setting $^{12}$ ), or a target population (mostly children ${ }^{13}$ ), or to some drug classes ${ }^{14}$ or some specialty (such as oncology, ${ }^{15}$ psychiatry $^{16}$ or rare diseases ${ }^{1}$ ).

The aim of this study was to describe off-label prescribing in French general practice, in terms of frequency and nature, and to identify its main determining factors.

\section{METHODS}

It was a multicentre cross-sectional study, carried out on general practice patients, in the French Rhône-Alpes region, as part of the Objectives of PREscriptions in general Medicine research programme ${ }^{17}$ It involved 23 training offices for interns from Lyon 1 University.

\section{Inclusion criteria}

Eleven general practice interns, acting as observers, have collected data during their training with a practitioner, and every intern was investigating in two to three different offices. We calculated a sample size of 2119 consultations, based on estimates of 2.9 drugs prescribed per consultation on average ${ }^{18}$ and of $20 \%$ of drugs prescribed off-label ${ }^{19}$ with a CI of $\pm 1 \%$. All the 2149 patients coming for a medical consultation or visited at home over a cumulative period of 5 days per office, between the second of November 2015 and the sixth of January 2016, were requested to the study. Eight patients refused to participate in the study. The database contained 2141 consultations, of which 1649 (77.0\%) included at least one drug prescription.

\section{Data collection and data entry}

Investigating interns benefited from training meetings for data collection and entry according to the International Classification of Primary Care (ICPC-2).$^{20}{ }^{21}$ At the end of each consultation, they collected the following variables on a free text questionnaire: consultation length, age, gender, socioprofessional category, potential fee exemption status (for low income or for long-term conditions), seniority of the patient (new or already known), health problems managed, and for each health problem, the prescribed drugs, their anteriority (new or renewed prescription) and the main goal of their prescription. Prescription goals were divided into three categories: specific (to decrease the risk of mortality or morbidity, to cure or provide remission of the disease), non-specific (to improve symptoms, quality of life or functional status) and unspecified. Following data have been collected on trainers: age, gender, practice location (rural, semirural or urban), type of practice (solo or collective), visits of pharmaceutical representatives and public health insurance representatives. Investigating interns have entered anonymous data previously collected on the paper questionnaires in a centralised database available on a dedicated website. They have entered the data on health problems managed according to the ICPC-2, using an online encoding engine. They have entered prescribed drugs using a search engine combined with the Thériaque drug database, ${ }^{22}$ which includes the Anatomical Therapeutic Chemical classification system. ${ }^{23}$ They entered the professions data according to the eight items of the French classification of professions and socioprofessional categories, ${ }^{24}$ before regrouping the data into five categories.

\section{Data analysis}

Each of the two reviewers (AN and FD) have analysed the 5036 drug prescriptions registered to identify drugs prescribed off-label in terms of indication or the age of the patient. In case of discrepancy, the two reviewers have consulted each other to find a compromise. In case of a disagreement, another author (LL) acted as arbitrator. We excluded 104 unusable drug prescriptions of the data analysis, due to indication inconsistencies $(n=33)$ or to drugs missing in the Thériaque database $(n=71)$. Our database contained 4932 drugs in the end. We used univariate, then multivariate analysis, based on hierarchical mixed-effects logistic regression to take into account the data structure. We selected the variables to include in the final model by doing a backward stepwise selection of the clinically relevant variables or those with a $p$ value less than 0.25 after the univariate analysis. The statistical significance threshold was set to $5 \%$ and $p$ values were obtained using likelihood ratio tests. We used R software V.3.1.0 to carry out the analyses.

\section{Patient and public involvement}

Patients and the public were not involved in the design of the study.

\section{RESULTS}

Among the 4932 drug prescriptions registered, 911 (18.5\% [95\% CI $17.4 \%$ to $19.6 \%$ ]) were off-label, of which $865(17.6 \%)$ due to the indication of the drug and $58(1.2 \%)$ due to the age of the patient. The proportion of consultations with at least one off-label drug was of $38.2 \%$ (95\% CI $35.8 \%$ to $40.6 \%$ ). The patient was never informed when prescriptions were off-label and prescriptions never mentioned the off-label use. The 10 most prescribed off-label drugs were: acetylsalicylic acid, omeprazole, diclofenac, salbutamol, prednisolone, amoxicillin, esomeprazole, mometasone, vitamin $\mathrm{D}$ and bisoprolol. Among them, the proportion of off-label prescriptions ranged from $17.8 \%$ to $76.2 \%$ (table 1 ). With the univariate analysis, variables contributing to off-label drug prescribing were the initiation of a new drug therapy $(\mathrm{OR}=1.27)$ and the non-specific goal of 
Table 1 Top 10 most prescribed off-label drugs in descending order $(n=4932)$

\begin{tabular}{lllll} 
& \multicolumn{2}{l}{ Off-label prescriptions } & \\
\cline { 2 - 4 } & $\begin{array}{l}\text { Yes } \\
\mathbf{n}(\%)\end{array}$ & $\begin{array}{l}\text { No } \\
\mathbf{n}(\%)\end{array}$ & $\begin{array}{l}\text { Total } \\
\mathbf{n}(\%)\end{array}$ & Main indication for off-label prescription \\
\hline Acetylsalicylic acid per os & $48(55.2)$ & $39(44.8)$ & $87(1.76)$ & Atherosclerosis/peripheral vascular disease \\
Omeprazole per os & $41(55.4)$ & $33(44.6)$ & $74(1.50)$ & Preventing NSAIDs ${ }^{\star}$-induced lesions \\
\hline Topical diclofenac & $28(49.1)$ & $29(50.9)$ & $57(1.16)$ & General pain/multiple pain locations \\
\hline Inhaled salbutamol & $21(46.7)$ & $24(53.3)$ & $45(0.91)$ & Acute bronchitis and bronchiolitis \\
Prednisolone per os & $20(45.4)$ & $24(54.6)$ & $44(0.89)$ & Cough \\
\hline Amoxicillin per os & $18(24.0)$ & $57(76.0)$ & $75(1.52)$ & Acute upper respiratory infection \\
\hline Esomeprazole per os & $17(30.4)$ & $39(69.6)$ & $56(1.14)$ & Epigastric/abdominal pain \\
\hline Nasal mometasone & $16(76.2)$ & $5(23.8)$ & $21(0.43)$ & Acute upper respiratory infection \\
Vitamin D per os & $16(17.8)$ & $74(82.2)$ & $90(1.83)$ & Osteoporosis \\
\hline Bisoprolol† per os & $16(39.0)$ & $25(61.0)$ & $41(0.83)$ & Uncomplicated hypertension \\
\hline
\end{tabular}

*Non-steroidal anti-inflammatory drugs.

†This bisoprolol off-label prescription only concerned Cardensiel and Bisoce, which have no MA for high blood pressure.

the medical prescription $(\mathrm{OR}=1.48)$; the age below or equal to 14 years $(\mathrm{OR}=1.44)$ and the profession of worker $(\mathrm{OR}=2.11)$ or the professional inactivity $(\mathrm{OR}=2.38)$ of the patient (table 2).

With the multivariate analysis, variables contributing to off-label prescribing were the number of drugs $(\mathrm{OR}=1.05$ for each additional drug), the initiation of a new drug therapy $(\mathrm{OR}=1.26)$ and the non-specific goal of the prescription $(\mathrm{OR}=1.43)$; the age of the patient below or equal to 14 years $(\mathrm{OR}=1.42)$; the rural location of the physician's practice $(\mathrm{OR}=1.38)$ and the low annual frequency of the visits of national health insurance representatives $(\mathrm{OR}=0.93)$ (table 3$)$. Using the receiver operating characteristic curve equation, the multivariate model explained $44.7 \%$ of the variance.

\section{DISCUSSION}

Almost one out of five drugs prescribed in general practice $(18.5 \%)$ was off-label in France, without informing the patient. Generally, a prescription has a higher risk of being off-label if it includes many newly prescribed drugs with a non-specific goal, for a patient less than 14 years old known by his GP, who is practising in a rural area and not meeting public health insurance representatives.

\section{Strengths and limitations}

No data were missing from the database we used. The off-label status of each drug prescription was double assessed. The multivariate analysis allowed us to take into account data hierarchy and to explain nearly $45 \%$ of the off-label prescription variance from the drug features, but also the patients and physicians characteristics. To the best of our knowledge, no previous study analysed all these combined factors. The study involved general practice trainers, which could entail a selection bias underestimating the off-label prescribing frequency. However, we observed that their patients and drug prescriptions were not very different from other GPs. ${ }^{25}$ In addition, mean age and gender of the participating GPs did not differ from French GPs (data not presented). We only studied off-label prescribing in terms of indication and age, without including the dosage, route of administration and drug interaction risks. Non-inclusion of these criteria allows us to believe that the estimation of off-label prescribing frequency was minimal.

\section{Comparison with existing literature}

Our estimation of off-label prescribing frequency (18.5\%) is close to the estimation of an American reference study (21\%) in community medicine in 2001, based only on the indication criteria. ${ }^{19}$ A French study in 2012, limited to 11 clinical situations, found that $19.3 \%$ of general practice prescriptions were off-label. ${ }^{26}$ Our results are even more significant given the high average level of drug prescribing in France, with more than $80 \%$ of general practice consultations resulting in at least one drug prescription. ${ }^{18}$ To the best of our knowledge, no previous study has examined patient information when they receive off-label prescriptions.

We can identify two types of off-label prescriptions: whether they are scientifically justified or not. Only $27 \%$ of off-label prescriptions were considered justified in the USA in 2001. ${ }^{19}$ Off-label prescribing is indeed not always wrong or harmful, especially when complying with clinical practice guidelines, since they are usually elaborated according to SPC. Available recommendations are in principle more adaptive and regularly updated, whereas indications remain most often unchanged after the MA, except for temporary recommendations for use. Moreover, most SPC labelling texts address regulatory or industrial issues rather than public health or clinical goals. They are, therefore, often limited or imprecise 
Open access

Table 2 Factors associated with off-label prescribing in univariate analysis

Off-label prescription

\begin{tabular}{c} 
Chara \\
\hline Drug \\
Ant
\end{tabular}

Yes $(n=911) \quad$ No $(n=4021) \quad$ Total $(n=4932) \quad$ OR

$\begin{array}{lllll}\mathrm{n}(\%) & \mathrm{n}(\%) & \mathrm{n}(\%) & (95 \% \mathrm{Cl}) & \mathrm{P}\end{array}$

Anteriority

\begin{tabular}{|c|c|c|c|c|c|}
\hline & & & & & \\
\hline Renewed & $444(48.7)$ & $2177(54.1)$ & $2621(53.2)$ & Reference & \\
\hline Initiated & $467(51.3)$ & $1844(45.9)$ & $2311(46.8)$ & 1.27 (1.08 to 1.48$)$ & \\
\hline Main goal & & & & & $<0.01$ \\
\hline Specific & $326(35.8)$ & $1791(44.5)$ & $2117(42.9)$ & Reference & \\
\hline Non-specific & $572(62.8)$ & 2164 (53.8) & $2736(55.5)$ & $1.48(1.26$ to 1.73$)$ & \\
\hline Unspecified & $13(1.4)$ & $66(1.6)$ & $79(1.6)$ & 1.14 (0.58 to 2.07$)$ & \\
\hline \multicolumn{6}{|l|}{ Patient/consultation } \\
\hline Age (years) & & & & & 0.01 \\
\hline $0-14$ & $145(15.9)$ & 477 (11.9) & $622(12.6)$ & 1.44 (1.13 to 1.83$)$ & \\
\hline $15-64$ & $381(41.8)$ & $1726(42.9)$ & $2107(42.7)$ & 1.05 (0.88 to 1.24$)$ & \\
\hline $65-100$ & $385(42.3)$ & $1818(45.2)$ & $2203(44.7)$ & Reference & \\
\hline Gender & & & & & 0.95 \\
\hline Female & $525(57.6)$ & $2310(57.4)$ & 2835 (57.5) & Reference & \\
\hline Male & $386(42.4)$ & $1711(42.6)$ & $2097(42.5)$ & 1.01 (0.86 to 1.18$)$ & \\
\hline Seniority & & & & & 0.20 \\
\hline New & $33(3.6)$ & $194(4.8)$ & $227(4.6)$ & Reference & \\
\hline Known & $878(96.4)$ & 3827 (95.2) & $4705(95.4)$ & 1.30 (0.88 to 1.98$)$ & \\
\hline $\begin{array}{l}\text { Fee exemption status for long-term } \\
\text { condition }\end{array}$ & & & & & 0.09 \\
\hline No & $623(68.4)$ & 2611 (64.9) & $3234(65.6)$ & Reference & \\
\hline Yes & $288(31.6)$ & $1410(35.1)$ & $1698(34.4)$ & 0.86 (0.73 to 1.02$)$ & \\
\hline Fee exemption status for low income & & & & & 0.17 \\
\hline No & $864(94.8)$ & $3852(95.8)$ & $4716(95.6)$ & Reference & \\
\hline Yes & $47(5.2)$ & $169(4.2)$ & $216(4.4)$ & 1.30 (0.89 to 1.86$)$ & \\
\hline Socioprofessional category & & & & & $<0.01$ \\
\hline Executive, intellectual profession & $13(1.4)$ & $114(2.8)$ & $127(2.6)$ & Reference & \\
\hline $\begin{array}{l}\text { Farmer/craftsman/shopkeeper/ } \\
\text { business owner/intermediate profession/ } \\
\text { employee }\end{array}$ & $193(21.2)$ & $916(22.8)$ & $1109(22.5)$ & $1.73(0.96$ to 3.37$)$ & \\
\hline Worker & $46(5.0)$ & $166(4.1)$ & $212(4.3)$ & 2.11 (1.07 to 4.38$)$ & \\
\hline Pensioner & $402(44.1)$ & $1966(48.9)$ & $2368(48.0)$ & $1.64(0.92$ to 3.17$)$ & \\
\hline Inactive & $257(28.2)$ & $859(21.4)$ & $116(22.6)$ & 2.38 (1.33 to 4.63$)$ & \\
\hline Duration $\geq 10 \mathrm{~min}$ & & & & & 0.75 \\
\hline Yes & $813(89.2)$ & $3619(90.0)$ & $4432(89.9)$ & Reference & \\
\hline No & $98(10.8)$ & $402(10.0)$ & $500(10.1)$ & $1.04(0.80$ to 1.35$)$ & \\
\hline $\begin{array}{l}\text { Number of health problems managed ( } m \\
\text { [SD]) }\end{array}$ & $2.9(2.0)$ & $3.1(2.1)$ & $3.0(2.1)$ & 0.97 (0.93 to 1.01$)$ & 0.09 \\
\hline Number of drugs (m [SD]) & $4.9(3.1)$ & $4.8(3.1)$ & $4.8(3.1)$ & $1.02(0.99$ to 1.05$)$ & 0.22 \\
\hline \multicolumn{6}{|l|}{ Physician } \\
\hline Age (years) & $49.9(7.7)$ & 49.7 (8.5) & $49.8(8.3)$ & 1.00 (0.99 to 1.02$)$ & 0.61 \\
\hline Gender & & & & & 0.66 \\
\hline Male & $596(65.4)$ & $2685(66.8)$ & $3281(66.5)$ & Reference & \\
\hline
\end{tabular}

Continued 


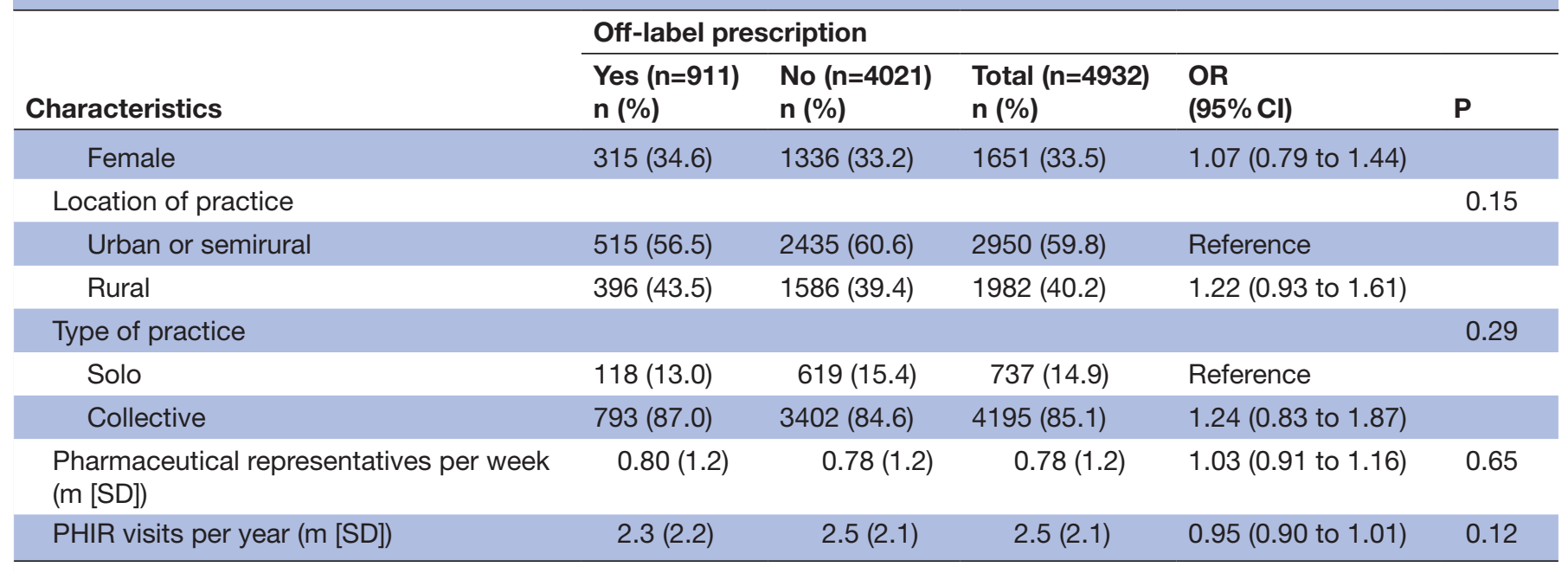

$\mathrm{m}$, mean; PHIR, public health insurance representatives.

Table 3 Factors associated with off-label prescribing in multivariate analysis

\begin{tabular}{|c|c|c|}
\hline Characteristics & OR (95\% Cl) & $\mathbf{P}$ \\
\hline \multicolumn{3}{|l|}{ Drug } \\
\hline Anteriority & & 0.02 \\
\hline Renewed & Reference & \\
\hline Initiated & $1.26(1.04$ to 1.54$)$ & \\
\hline Main goal & & 0.0001 \\
\hline Specific & Reference & \\
\hline Non-specific & $1.43(1.21$ to 1.67$)$ & \\
\hline Unspecified & $1.16(0.62$ to 2.18$)$ & \\
\hline \multicolumn{3}{|l|}{ Patient/consultation } \\
\hline Age (years) & & 0.04 \\
\hline $0-14$ & $1.42(1.07$ to 1.88$)$ & \\
\hline $15-64$ & 1.07 (0.87 to 1.30$)$ & \\
\hline $65-100$ & Reference & \\
\hline Seniority & & 0.049 \\
\hline New & Reference & \\
\hline Known & 1.51 (1.00 to 2.27$)$ & \\
\hline Number of drugs ${ }^{\star}(\mathrm{m}[\mathrm{SD}])$ & 1.05 (1.02 to 1.09$)$ & 0.002 \\
\hline \multicolumn{3}{|l|}{ Physician } \\
\hline Practice location & & 0.02 \\
\hline Urban or semirural & Reference & \\
\hline Rural & 1.38 (1.08 to 1.75$)$ & \\
\hline $\begin{array}{l}\text { PHIR visits per yeart (m } \\
\text { [SD]) }\end{array}$ & $0.93(0.88$ to 0.98$)$ & 0.02 \\
\hline
\end{tabular}

*For each new drug per consultation, the probability of off-label prescribing was multiplied by 1.05 .

†PHIR, public health insurance representatives. Off-label prescribing probability decrease by $7 \%$ for each additional visit per year.

m, mean. and not well suited for clinical use, especially in general practice. ${ }^{1}$ For example, among the 10 most prescribed off-label drugs identified in our study, acetylsalicylic acid has no indication for peripheral artery disease while it is recommended by the French National Authority for Health (HAS) in that indication, ${ }^{27}$ and it is even a criterion of the public health pay-for-performance system. ${ }^{28}$ Omeprazole is also not indicated for the prevention of non-steroidal anti-inflammatory drugs (NSAIDs)-induced lesions, while it is one of the proton pump inhibitors (at full dose) recommended by the HAS in this indication. ${ }^{29}$ In these situations, should the physician respect the regulation, the patient would not be reimbursed for a drug with no MA in this indication. On the opposite, some off-label prescriptions in our study were not justified. Salbutamol was prescribed off-label to treat bronchiolitis in infants and acute bronchitis in adults, while it is not recommended in these two indications. ${ }^{30}$ Amoxicillin was prescribed off-label for upper respiratory tract infections, acute nasopharyngitis in particular, contrary to clinical practice guidelines. ${ }^{31}$ Prednisolone was also prescribed off-label as cough treatment, despite no proven efficacy in reducing the symptoms duration or severity. ${ }^{32}$ Esomeprazole was prescribed off-label for epigastric pain, despite the suspicion of serious adverse effects when using proton pump inhibitors for an extended period. ${ }^{33}$

Off-label prescribing is legal in France and physicians can freely prescribe if their prescription is in line with the 'current scientific knowledge'. ${ }^{34}$ However, the physician is liable for off-label prescribing, and has to justify the validity of his prescription by the lack of alternative drugs and the absolute necessity of the treatment. He must also inform the patient on potential risks and that the prescription is non-reimbursable, before obtaining his informed consent. ${ }^{35}$ Not informing the patient has already been considered a prejudice punishable by law in France. ${ }^{36}$ We can assume that in some situations the physician did not intentionally prescribe off-label. This 
can partly be explained by the lack of clarity of some SPC that is hard to remember for practitioners. Indications can change within a therapeutic class, or between an original drug and its generics. For example, different topical NSAIDs have specific indications in terms of aetiology (trauma, osteoarthritis, etc) and of location (knee, finger, etc). The branded versions of bisoprolol (Cardensiel) do not have an MA to treat high blood pressure, but its generics are indicated in uncomplicated high blood pressure. On the contrary, the branded versions of pregabalin (Lyrica) are indicated to treat neuropathic pain, but its generics are not.

We observed more frequent off-label prescriptions when they did not have a specific goal. More than half of the drugs are prescribed without a specific goal in general practice, mostly to alleviate symptoms. ${ }^{17}$ The patients' high expectations in these situations could explain these off-label prescriptions. Our study confirms that children are especially exposed to off-label prescriptions $(23.3 \%)$. Previous studies mainly included children and did not compare children and adults. In 2011, a French study estimated that almost $38 \%$ of community medicine prescriptions for children were off-label, based on indication, dosage, age or route of administration. ${ }^{37} \mathrm{~A}$ systematic literature review found that $11 \%-37 \%$ of community medicine prescriptions for children were off-label. ${ }^{13}$ This can be explained by the lack of clinical trials for this population deemed at risk. ${ }^{38}$ In the field of analgesics, in particular, many drugs are recommended, although they have not been tested in children and thus, have no MA. ${ }^{39} \mathrm{On}$ a European level, new rules have been established as part of 'The European Regulation on medicines for paediatric use' programme, to promote drug development for children. ${ }^{40}$ Some drugs may later obtain an MA for use in children although such use was originally off-label. In addition, real-world evidence on use in such off-label populations is sometimes used to providing supporting evidence for MA applications in new populations. ${ }^{41}$

The more drugs prescribed during a consultation, the higher the chances of being off-label. This cumulative risk could contribute to increase the probability of adverse effects linked to polypharmacy (estimated to be between $6 \%$ and $15 \%$ per additional drug). ${ }^{42}$ Our results confirm a higher off-label frequency in rural areas, already observed in a study in German children. ${ }^{43}$ Difficulties to access continuing education because of isolation may explain this finding. The lower frequency of off-label prescriptions observed in physicians meeting with public health insurance representatives is probably linked to the fact that they remind them of good medical practices and provide them with prescribing guidelines based on current recommendations. ${ }^{44}$ In our study, meeting with pharmaceutical industry representatives did not increase off-label prescribing, but it was shown that it increased the amount and cost of prescribed drugs, and lowered the quality of drug prescriptions. ${ }^{45}$

\section{Implications for practice and research}

These results raise issues in terms of education and prescription support systems. According to a French report on promoting and monitoring the proper use of medicinal products, physicians do not have enough training on basic rationales that are the foundation of good prescribing and relevant use of drugs. The authors of this report recommend improving initial medical training, to make the prescribing physician aware of what he is prescribing, to whom, how and why. In their opinion, the lack of continuing education and of the hierarchy of its content regarding health and economic priorities are significant factors of improper prescribing, particularly off-label. $^{46}$

Practitioners' drug prescription software are not effective enough, even those certified by the HAS. ${ }^{46}$ It would be advisable that these software include a prescribing support system displaying every data available on drug benefits and risks for each indication. In principle, the physician should associate the drug to the diagnosis justifying his prescription. ${ }^{47}$ His software should then be able to indicate if this diagnosis is part of the drug MA, considering the patient's age. Whether or not the drug has an MA in the intended indication, the software should be able to suggest the treatment options supported by clinical practice recommendations or by scientific data. ${ }^{48}$ In the USA, Drugdex system is a national reference standard for drug use, describing the level of evidence of their efficacy and their safety in every indication, covered by an MA or not. The Medicaid software uses this tool to approve the reimbursement of treatments prescribed in off-label indications based on a sufficient level of evidence. ${ }^{49}$

Developing a postmarketing drug surveillance system that measures the drug effectiveness and risks in routine practice would secure prescriptions, and in particular off-label prescriptions, that involve major adverse effect risks. ${ }^{50}$ In France, there is a 'temporary recommendation for use' process allowing to monitor temporary off-label prescribed drugs for indications for which they are not licenced yet, and to evaluate them to prepare an MA application. This regulatory process is intended for specific groups of patients and rare diseases, and does not really concern GPs. ${ }^{51}$

There is no official definition for off-label prescribing and various definitions are used. ${ }^{52}$ An international or European common definition would allow better off-label prescriptions evaluation and comparison. The intentionality requirement, by the EMA, in particular, ${ }^{1}$ can be an obstacle as this criterion is hard to assess.

\footnotetext{
Author affiliations

${ }^{1}$ Univ. Lyon, Université Claude Bernard Lyon 1, Université Saint-Étienne, Collège universitaire de médecine générale, F-69008 Lyon, F-42023 Saint-Étienne,

Département de médecine générale, Lyon, France

${ }^{2}$ Service de Biostatistique, Centre Hospitalier Universitaire de Lyon, Lyon, France ${ }^{3}$ Département de pharmacie, Centre Hospitalier Universitaire de Lyon, Lyon, France ${ }^{4}$ Département d'enseignement et de recherche en Médecine Générale, Universite de Nice Faculte de Medecine, Nice, France
} 
${ }^{5}$ EPICIME-Centre d'Investigation Clinique, INSERM CIC201/UMR5558, Hôpital Louis Pradel, Lyon, France

${ }^{6}$ UMR 5558, CNRS Lyon, University of Lyon 1, Lyon, France

${ }^{7}$ Univ. Lyon, Université Claude Bernard Lyon 1, Université Saint-Étienne, HESPER EA 7425, F-69008 Lyon, F-42023 Saint-Étienne, France, E.A. 4129 « Santé, Individu, Société », Lyon, France

Acknowledgements We would like to thank Louis Bernard who supervised the data collection, and the interns who collected the data: Morgane Aillet, Sofien Amraoui, FD, Florent Debruyne, Aurélie Fleurentin, Laura Laperriere, Thomas Lecocq, Lucile Moracchini, AN, Arnaud Ponçon and Manon Ubéra. We also thank their $23 \mathrm{GP}$ trainers. We are indebted to Philippe Ameline, who developed the server for data entry and storage. We are grateful to Natane Reynaud for the English editing of the manuscript.

Contributors LL conceived the study and designed it along with FD and AN. $\mathrm{XD}$ helped to use the Thériaque drug database. AN and FD identified the drugs prescribed off-label, with the support of LL. JG performed statistical analyses. BK and DD contributed to the interpretation of the findings. AN, FD and LL drafted the manuscript. All authors reviewed and approved the final version of the article.

Funding None, neither for this study nor for the original OPREM study. Competing interests None declared.

Patient consent for publication Not required

Ethics approval The Ethics Committee of the Hospices Civils de Lyon approved the OPREM research program, including the present study ( $\left.\mathrm{N}^{\circ} 15-02\right)$.

Provenance and peer review Not commissioned; externally peer reviewed.

Data sharing statement The database is available on request from the corresponding author.

Open access This is an open access article distributed in accordance with the Creative Commons Attribution Non Commercial (CC BY-NC 4.0) license, which permits others to distribute, remix, adapt, build upon this work non-commercially, and license their derivative works on different terms, provided the original work is properly cited, appropriate credit is given, any changes made indicated, and the use is non-commercial. See: http://creativecommons.org/licenses/by-nc/4.0/.

\section{REFERENCES}

1. Weda M, Hoebert J, Vervloet M, et al. Study on off-label use of medicinal products in the European Union. Brussels: European Union, 2017. https://www.google.com/url?sa=t\&rct=j\&q=\&esrc= s\&source $=$ web\&cd $=1 \& c a d=$ rja\&uact $=8 \&$ ved $=2$ ahUKEwixk $4 \mathrm{bAhPP}$ eAhUjpYsKHamdA7MQFjAAegQICRAC\&url=https\%3A\%2F\% 2Fec.europa.eu\%2Fhealth\%2Fsites\%2Fhealth\%2Ffiles\%2Ffiles $\%$ 2Fdocuments\%2F2017 0228 final study report on off-label use pdf\&usg=AOvVaw2j8iVINjF3puOqgcEvrv3- (Accessed 23 Nov 2018).

2. Food and drug administration. Development \& approval process (drugs). 2017 https://www.fda.gov/Drugs/DevelopmentApprovalP rocess/default.htm\#FDA (Accessed 23 Nov 2018).

3. Nathan JP, Vider E. The Package Insert. USPharm 2015;40:8-10.

4. European Medicines Agency. About us. 2017 https://www. google. $\operatorname{com} /$ url? sa =t\&rct=j\&q=\&esrc $=$ s\&source $=$ web\&cd $=1 \&$ ved $=$ 2ahUKEwjLuq6f_PLeAhVIFywKHWnIDQsQFjAAegQIChAC\&url= https\%3A\%2F\%2Fwww.ema.europa.eu\%2Fdocuments\%2Fother\% 2Fabout-us-european-medicines-agency-ema_en.pdf\&usg=AOvV aw2kOvVtx7SpKfaGl4oq5Rsy (Accessed 23 Nov 2018).

5. Hermange MT, Payet AM. Rapport d'information $n^{\circ} 382$ du Sénat au nom de la Commission des Affaires Sociales sur les conditions de mise sur le marché et de suivi des médicaments. Paris: Sénat, 2006. https://www.senat.fr/rap/r05-382/r05-3821.pdf. (Accessed 23 Nov 2018).

6. Applying for EU marketing authorization - For medicinal products for human use. London: European Medicines agency, 2015. https:// www.google.com/url?sa $=$ t\&rct $=\mathrm{j} \& \mathrm{q}=\&$ \& src $=$ s\&source $=$ web\&cd $=2 \&$ ved=2ahUKEwiC1N7v_PLeAhUGjywKHcgvDOEQFjABegQIBBAC\& url=https $\% 3 A \% 2 F \% 2$ Fwww.ema.europa.eu $\% 2$ Fdocuments $\%$ 2Fleaflet\%2Fapplying-eu-marketing-authorisation-medicinalproducts-veterinary-use_en.pdf\&usg=AOvVaw2MccT1k1ZTklg7 Ji1lO5_n. (Accessed 23 Nov 2018).

7. Enterprise and industry directorate-general. A guideline on summary of product characteristics (SmPC. Brussels: European commission, 2009. https://www.google.com/url?sa=t\&rct=j\&q=\&esrc=s\&source= web\&cd=1\&ved=2ahUKEwjszPTR_fLeAhVGISwKHfWGCHoQF
jAAegQICRAC\&url=https\%3A\%2F\%2Fec.europa.eu $\% 2 F$ health\% 2Fsites\%2Fhealth\%2Ffiles\%2Ffiles\%2Feudralex\%2Fvol-2\%2Fc\% 2Fsmpc_guideline_rev2_en.pdf\&usg=AOvVaw0ZsfL9y7ye3DfJ J6oo9OSf. (Accessed 23 Nov 2018).

8. Reggi V, Balocco-Mattavelli R, Bonati M, et al. Prescribing information in 26 countries: a comparative study. Eur J Clin Pharmacol 2003;59:263-70.

9. Eguale T, Buckeridge DL, Verma A, et al. Association of off-label drug use and adverse drug events in an adult population. JAMA Intern Med 2016;176:55-63.

10. Smyth RM, Gargon E, Kirkham J, et al. Adverse drug reactions in children--a systematic review. PLoS One 2012;7:e24061.

11. Stafford RS. Regulating off-label drug use--rethinking the role of the FDA. N Engl J Med 2008;358:1427-9.

12. Cras A, Conscience MA, Rajzbaum G, et al. Off-label prescribing in a French hospital. Pharm World Sci 2007;29:97-100.

13. Pandolfini C, Bonati M. A literature review on off-label drug use in children. Eur J Pediatr 2005;164:552-8.

14. Szeinbach SL, Williams B, Muntendam $P$, et al. Identification of allergic disease among users of antihistamines. J Manag Care Pharm 2004;10:234-8

15. Casali PG. Executive Committee of ESMO. The off-label use of drugs in oncology: a position paper by the European Society for Medical Oncology (ESMO). Ann Oncol 2007;18:1923-5.

16. Martin-Latry K, Ricard $\mathrm{C}$, Verdoux $\mathrm{H}$. A one-day survey of characteristics of off-label hospital prescription of psychotropic drugs. Pharmacopsychiatry 2007;40:116-20.

17. Bernard L, Ecochard R, Gueyffier F, et al. Drug prescription goals in primary care: a cross-sectional study. 2018.

18. Amar E, Pereira C. Les prescriptions des médecins généralistes et leurs déterminants. Études et résultats 2005;440:1-12

19. Radley DC, Finkelstein SN, Stafford RS. Off-label prescribing among office-based physicians. Arch Intern Med 2006;166:1021-6.

20. The International Classification of Primary Care, Revised second edition (ICPC-2). Oxford: Oxford University Press, 2005:193.

21. International classification of primary care. 2nd ed (ICPC-2). Geneva: WHO, 2003. http://www.who.int/classifications/icd/adaptations/ icpc2/en/. (Accessed 23 Nov 2018).

22. Husson MC. [Theriaque: independent-drug database for good use of drugs by health practitioners]. Ann Pharm Fr 2008;66:268-77.

23. Anatomical Therapeutic Chemical (ATC) classification system. Oslo: WHO Collaborating Centre for Drug Statistics Methodology, 2018. https://www.whocc.no/atc/structure_and_principles/. (Accessed 23 Nov 2018).

24. Classification of professions and socioprofessional categories. Montrouge: The French National Institute of Statistics and Economic Studies, 2003. https://www.insee.fr/en/metadonnees/definition/ c1493. (Accessed 23 Nov 2018).

25. Letrilliart L, Rigault-Fossier P, Fossier B, et al. Comparison of French training and non-training general practices: a cross-sectional study. BMC Med Educ 2016;16:126.

26. Geoffroy-plasqui M, Raineri F, Arnould P, et al. La prescription hors autorisation de mise sur le marché en médecine générale. Exercer 2012;100:44-5.

27. Recommandation pour la pratique clinique : Prise en charge de l'artériopathie chronique oblitérante athéroscléreuse des membres inférieurs. Saint-Denis: HAS, 2006. https://www.has-sante.fr/portail/ upload/docs/application/pdf/AOMI_recos.pdf. (Accessed 23 Nov 2018).

28. Maladie A. Antiagrégants plaquettaires. 2012 https://www.ameli.fr/ sites/default/files/Documents/5045/document/memo-antiagregantsplaquettaires assurance-maladie.pdf (Accessed 23 Nov 2018).

29. HAS. Les inhibiteurs de la pompe à protons chez l'adulte. 2009 https://www.has-sante.fr/portail/jcms/c_812066/fr/les-inhibiteursde-la-pompe-a-protons-chez-l-adulte-fiche-bum (Accessed $23 \mathrm{Nov}$ 2018).

30. Ralston SL, Lieberthal AS, Meissner HC, et al. Clinical practice guideline: the diagnosis, management, and prevention of bronchiolitis. Pediatrics 2014;134:e1474-e1502.

31. Wong DM, Blumberg DA, Lowe LG, et al. Guidelines for the use of antibiotics in acute upper respiratory tract infections. Am Fam Physician 2006;74:956-66.

32. Hay AD, Downing HE, Brookes ST, et al. S87 Are oral steroids effective in treating the symptoms of acute lower respiratory tract infection in non-asthmatic adults? The Oral Steroids for Acute Cough (OSAC) placebo-controlled randomised trial. Thorax 2015;70:A50.1-A50

33. Chen J, Yuan YC, Leontiadis GI, et al. Recent safety concerns with proton pump inhibitors. J Clin Gastroenterol 2012;46:93-114.

34. Conseil National de l'Ordre des Médecins. Liberté de prescription. Code de déontologie médicale, 2017. https://www.conseil-national. 
medecin.fr/article/article-8-liberte-de-prescription-232. (Accessed 23 Nov 2018).

35. Aagaard L, Kristensen K. Off-label and unlicensed prescribing in Europe: implications for patients' informed consent and liability. Int $J$ Clin Pharm 2018;40:509-12.

36. Cour de cassation, civile, Chambre civile 1, 12 juin 2012, Pourvoi $\mathrm{n}^{\circ}$ 11-18327. https://www.legifrance.gouv.fr/affichJuriJudi.do? oldAction=rechJuriJudi\&idTexte=JURITEXT000026027743 (Accessed 23 Nov 2018).

37. Palmaro A, Bissuel R, Renaud N, et al. Off-label prescribing in pediatric outpatients. Pediatrics 2015;135:49-58.

38. Frattarelli DA, Galinkin JL, Green TP, et al. Off-label use of drugs in children. Pediatrics 2014;133:563-7.

39. Association of Paediatric Anaesthetists of Great Britain and Ireland. Guidance for the administration of codeine and alternative opioid analgesics in children. London: Association of Paediatric Anaesthetists, 2013. https://www.google.com/url?sa=t\&rct=j\&q=\& esrc $=$ s\&source $=$ web\&cd $=2 \& c a d=$ rja\&uact $=8 \& v e d=2 a h U K E w j N p L n-$ fLeAhVE1iwKHc2dBusQFjABegQIBBAC\&url=https\%3A\%2F\% 2Fwww.rcoa.ac.uk\%2Fsystem\%2Ffiles\%2FCodeineGuidance2013. pdf\&usg=AOvVaw3oCBpVc_LBuMrV8b7F2NJy. (Accessed 23 Nov 2018).

40. Dunne J. The European Regulation on medicines for paediatric use. Paediatr Respir Rev 2007;8:177-83.

41. Musters A, Assaf A, Gerlag DM, et al. Discovery of innovative therapies for rare immune-mediated inflammatory diseases via offlabel prescription of biologics: The Case of IL-6 receptor blockade in castleman's disease. Front Immunol 2015;6:625.

42. Gandhi TK, Weingart SN, Borus J, et al. Adverse drug events in ambulatory care. N Engl J Med 2003;348:1556-64.

43. Sonntag D, Trebst D, Kiess W, et al. [Off-label drug prescriptions among outpatient children and adolescents in Germany--a database analysis]. Dtsch Med Wochenschr 2013;138:2239-45.
44. Assurance Maladie. Le service de contrôle médical. 2009 https:// www.ameli.fr/l-assurance-maladie/connaitre-l-assurance-maladie/ missions-et-organisation/le-reseau-de-l-assurance-maladie/leservice-du-controle-medical.php (Accessed 13 Nov 2018).

45. Spurling GK, Mansfield PR, Montgomery BD, et al. Information from pharmaceutical companies and the quality, quantity, and cost of physicians' prescribing: a systematic review. PLoS Med 2010;7:e1000352.

46. Bégaud B, Costagliola D. Rapport sur la surveillance et la promotion du bon usage du médicament en France. 2013 http://solidaritessante.gouv.fr/IMG/pdf/Rapport_Begaud_Costagliola.pdf (Accessed 23 Nov 2018).

47. De Vries $\mathrm{T}$, Hennings $\mathrm{R}$, Horgerzeil $\mathrm{H}$, et al. Guide to good prescription. WHO Action programme on essential drugs. 1995 http://apps.who.int/iris/bitstream/10665/59001/1/WHO_DAP_94.11. pdf (Accessed 23 Nov 2018).

48. Maxwell S, Eichler HG, Bucsics A, et al. e-SPC - delivering drug information in the 21st century: developing new approaches to deliver drug information to prescribers. $\mathrm{Br} \mathrm{J}$ Clin Pharmacol 2012;73:12-15

49. Center for Medicare Advocacy. CMA report: medicare coverage for off-label drug use. 2010 http://www.medicareadvocacy.org/cmareport-medicare-coverage-for-off-label-drug-use/ (Accessed 23 Nov 2018).

50. Dal Pan GJ. Monitoring the safety of medicines used off-label. Clin Pharmacol Ther 2012;91:787-95.

51. Emmerich J, Dumarcet N, Lorence A. France's new framework for regulating off-label drug use. N Engl J Med 2012;367:1279-81.

52. Mason J, Pirmohamed M, Nunn T. Off-label and unlicensed medicine use and adverse drug reactions in children: a narrative review of the literature. Eur J Clin Pharmacol 2012;68:21-8. 